\title{
STATUTORY STRICT LIABILITY FOR AN INSURER'S FAILURE TO SETTLE: A BALANCED PLAN FOR AN UNRESOLVED PROBLEII
}

\author{
VICTOR E. SCHWARTZ*
}

\section{INTRODUCTION}

Every time a hability insurance policyholder causes an accident, he has a potential legal battle, not only with the party he injured, but also with his liability insurance company. This occurs nost often when the insurance company declines an offer of settlement within the amount of the insured's liability imsurance policy and, subsequently, a verdict is rendered against the insured for an amount in excess of his liability insurance coverage. ${ }^{1}$

The insured may be able to recover this excess in a suit against his insurance company because the hability insurance company improperly represented his interest: in deciding "not to settle," it placed its own interests above that of its chent. ${ }^{2}$ In determining when the in-

* LI.B. Columbia University, 1965; Professor of Law, University of Cincinnati. Professor Schwartz will be a co-author of the next edition of W. Prosser \& J. WADE, CASEs and Materiats on Torts (The Foundation Press, Inc.). He is also the author of the treatise Comparative Negligence (The Allen Smith Co. 1974). Currently he serves as Chairman of the Faculty Liaison Committee of the section on Insurance, Neghigence and Conpensation Law of the American Bar Association.

The author expresses his appreciation to Ms. Anne Voegtlen, a third-year student at the University of Cincinnati College of Law, for her assistance in the research for this Article.

1. See, e.g., Keeton, Liability Insurance and Responsibility for Settlement, 67 HARv. L. Rev. 1136 (1954); Smith, The Miscegenetic Union of Liability Insurance and Tort Process in the Personal Injury Claims System, 54 CoRNeLx L. Rev. 645 (1969); Snow, Excess Liability_Crisci \& Lysick, 36 INs. Counsel J. 51 (1969); 23 U. FLA. L. REv. 201 (1970). See also Brassil v. Maryland Cas. Co., 210 N.Y. 235, 104 N.E. 622 (1914), where it was first recognized, by implication, that a conflict of interests existed between insurer and insured when a settleinent offer within policy limits is refused. Until that time, courts had interpreted companies' "right" to settle literally.

2. See, e.g., Brassil v. Maryland Cas. Co., 210 N.Y. 235, 240-41, 104 N.E. 622, 624 (1914):

[T]le true neasure of the rights of the plaintiff [insured] on the one band and of the obligations of the defendant [insurance] company on the other is not otbe found in the letter of the contract of insurance. That contract, by its very terms, was designed to exclude any such liability. But there is a contractual obligation of universal force which underlies all written agreements. It is the obligation of good faith in carrying out what is written. The defendant's failure to observe this requirement . . . is the thing upon which its liability nuay safely be predicated.

Snow, supra note 1, at 51-54; Annot., 40 A.L.R.2d 168 (1955). 
surance company should pay this excess judgment, a number of courts have resorted to a subjective standard and deemed the insurance company liable only when it has exercised "bad faith" in failing to settle." Other courts have predicated liability on a general negligence standard. Fimally, at least two courts have proposed that liability insurance compamies might be deemed. strictly liable when their failure to settle has resulted in an excess judgment against their insured, but these decisions have not provided a developed rationale for their suggestion. ${ }^{5}$

None of the approaches utilized by courts las met with a great deal of approval." Both the "good faith" and "negligence" standards have failed to provide meaningful predictability that is so necessary in

3. R. Keeton, Basic TeXt on Insurance LaW $\$ 7.8($ b), at 510 (1971). See Board of Educ. v. Lumbermens Mut. Cas. Co., 293 F. Supp. 541 (D.N.J. 1968), aff'd per curiam, 419 F.2d 837 (3d Cir. 1969); Brown v. Guarantee Ins. Co., 155 Cal. App. 2d 679, 689, 319 P.2d 69, 75 (1957) (list of factors involved in "good faith"); Koppie v. Allied Mut. Ins. Co., 210 N.W.2d 844 (Iowa 1973); Lange v. Fidelity \& Cas. Co., 290 Minn. 61, 185 N.W.2d 881 (1971); Bowers v. Camden Fire Ins. Ass'n, 51 N.J. 62, 237 A.2d 857 (1968); Crabb v. National Indem. Co., 205 N.W.2d 633 (S.D. 1973); Annot., 40 A.L.R.2d 168, $\$ \S 4-5$ at 178-83 (1955).

4. R. KeETON, supra note $3, \S 7.8(\mathrm{~b})$, at 510. See American Underwriters Ins. Co. v. Shook, 247 Ark, 1082, 449 S.W.2d 402 (1970); Dumas v. State Farm Mut. Auto. Ins. Co., 111 N.H. 43, 274 A.2d 781 (1971); Annot., 40 A.L.R.2d 168, § 7, at 18690 (1955).

Although bad faith and negligence standards are nominally distinct, the two tend to coalesce in practice. See, e.g., Hills \& Pivnicka, Development and Direction of the California Bad Faith Insurance Doctrine or "O Ye of Little Faith" 8 U.S.F. L. REv. 29 (1973); Keeton, Ancillary Rights of the Insured Against His Liability Insurer, 13 VAND. L. Rev. 837, 851-53 (1960); Comment, Approaching Strict Liability of Insurer for Refusing to Settle Within Policy Limits, 47 NEB. L. REv. 705, 714-17 (1968); Comment, Insurer's Liability in Excess of Policy Limits, 15 S.D.L. Rev. 143, 151-53 (1970); Note, Liability Insurance-The Movable Link Between Coverage Denial and Settlement Offers, 52 N.C.L. Rev. 703 (1974).

5. Crisci v. Security Ins. Co., 66 Cal. $2 \mathrm{~d} 425,431,426$ P.2d 173, 177, 58 Cal. Rptr. 13, 17 (1967); Rova Farms Resort, Inc. v. Investors Ins. Co. of America, 65 N.J. 474, 501-02, 323 A.2d 495, 510 (1974).

6. Huttenbrauck, Effect of Insured's Bad Faith Refusal to Settle on Insurer's Liability for Excess Judgment, 7 The Forum 61, 63 (1972); Comment, Applying the Bad Falth Doctrine to the Primary and Excess Insurance Carrier Relationship in California, 7 Loyola L.A.L. REv. 277 (1974); Comment, Insurance-Liability of Insurer for Judgment in Excess of Policy Limits, 48 Mrch. L. Rev. 95, 100-03 (1949). See, e.g., Slater v. Motorists Mut. Ins. Co., 174 Ohio St. 148, 152, 187 N.E.2d 45, 48 (1962) (insurance company's behavior characterized as "arbitrary and a display of poor judgment," but not bad faith); Appleman, Duty of Liability Insurer to Compromise Litigation, 26 KY. L.J. 100 (1938) (judged negligence and bad faith standards acceptable in theory, but unworkable in practice). Appleman characterized "a group of laymen casually assembled" as "absolutely incompetent" to apply either test accurately. Id. at 111. Even those who disagree must recognize that juries may be prone to direct their sympathies toward vulnerable insureds. Jarrett, Lawsuits for Wrongful Refusal to Defend or to Settle, 28 INs. COUNSEL J. 58, 62 (1961). 
this area. It is very difficult for the insurance company to know whether or not its failure to settle may subject it to future liability against the insured. Thus, it cannot make an accurate determination of the premium on the policies it issues.

The uncertainties involved are equally serious for the insured. He could have avoided personal payment in regard to the tort claim lodged against him "if only" his insurer had accepted the offer of settlement. Now he must absorb what is often a substantial incursion into his assets-savings, car or home-in order to pay off the tort claim. ${ }^{\top}$ He may attempt to place this loss on his insurance company, but there are serious obstacles in his way.

He must find an attorney to take his case. This may not be an easy task. These suits are most unpopular ones with insurance companies, and members of the plaintiff's bar who inust deal in a satisfactory manner with that class of defendants every working day may be reluctant to take such cases. Even if the attorney is willing to "go after" the insurance company, the economics of the case may make him reluctant to proceed because recovery is uncertain. In that regard, the attorney's hesitancy may be increased because of the substantial costs of experts and personal time involved in a case of this type. ${ }^{8}$

If the insurance companies were made strictly liable for their failure to settle, this would allow for a greater degree of prediction for both the insurer and the insured. Nevertheless, a carefully articulated rationale must be provided for the imposition of strict liability. Also, strict liability has the unfortunate potential of subjecting liability insurance companies to extraordinarily high costs and causing the price of liability insurance to rise. The result may be that fewer and fewer individuals will purchase it. This is an unhappy consequence, assuming that our society wishes to achieve the goal of spreading the cost of accidents in a fair and reasonable manner.

Legal problems relating to failure to settle not only adversely affect insurance compaines and their insureds. Recently some courts have held that liability insurance company attorneys may also be subject to a successful malpractice charge by policyholders when the attorney has placed the company's interest above that of the liability insurance holder. ${ }^{9}$ This has placed insurance company attorneys in a

7. For a detailed account of the serious personal consequence that can befall an insured in this situation, see Crisci v. Security Ins. Co., 66 Cal. $2 \mathrm{~d} \mathrm{425,} 426 \mathrm{P.2d} 173$, 58 Cal. Rptr. 13 (1967).

8. Cf. J. O'CONNELL, ENDING Insult to INJURY 18-19 (1975) (cost of experts in products liability cases).

9. See Lysick v. Walcom, 258 Cal. App. 2d 136, 65 Cal. Rptr. 406 (1968); Ivy 
highly precarious position. When should they withdraw from the case? Can they ever serve both the insured and the insurance company simultaneously once an offer of settlement has been tendered?

Is there a viable solution to the problem of allocating costs when an insurance company's judgment in failing to settle proves to be wrong? Can this solution end the conflict of interest dilemma that insurance company attorneys who defend policyliolders face daily? Some freslı thinking is called for; hopefully, it will be provided herein.

\section{The Insurance Company Attorney Withdraws From REPRESENTING THE INSURED-A SOLUTION?}

One solution to the problem lias been suggested by the American Bar Association: provide that the insurance company attorney advise the insured of the conflict of interest as soon as it arises and withdraw from representing the insured if it becomes apparent that there is an actual conflict of interest. ${ }^{10}$ While this approach may be the only viable solution when the conflict of interest is based on the fact that the insurance coinpany is on "both sides" of the same case, ${ }^{11}$ or when it is in dispute with the policyholder as to "coverage,"12 it is not very promising in cases where a conflict of interest arises out of a refusal by the insurance company to settle. In that regard, if the insurance company attorney withdraws from representation, who is to represent the insured in the liability case against him? An attorney recommended by the insurance company inay not have the degree of independence that is required in this situation. More importantly, the insured must pay independent defense counsel and this cost will be substantial. The insured is unlikely to accept the insurance company's offer to withdraw when he is not in a position to pay an attorney. On the other liand, it is unreasonable to coinpel the insurance company

v. Pacific Auto Ins. Co., 156 Cal. App. 2d 652, 320 P.2d 140 (1958); Annot., 28 A.L.R.3d 389, 396-97 (1969); Annot., 17 A.L.R.3d 835, 848-49 (1968).

10. See ABA Code of Professional Responsibility, Canon 5; American Bar AsSOCIATION STATEMENTS OF PRINCIPLES, LiABILITY INSURERS IV (1972).

11. This can occur when, for instance, both drivers in an automobile accident are insured by the same insurer. See generally R. KeEton, supra note 3, \$ 7.7(a) (1971).

12. For example, the insured may contend that his liability, if any, is in negligence, while the insurance company could allege noncoverage because the imsured committed an intentional tort. See Ferguson v. Birmingham Fire Ins. Co., 254 Ore. 496, 460 P.2d 342 (1969) (insurer has duty to defend when complaint on one count falls within coverage); Alm v. Hartford Fire Ins. Co., 369 P.2d 216 (Wyo. 1962) (insurer has duty to defend when complaint alleged potential coverage); Newcomb v. Meiss, 263 Minn. 315, 116 N.W.2d 593 (1962) (in negigence action not error to refuse request of insurance company counsel to submit issue of intentional tort to jury). 
to pay for independent counsel every time a potential conflict of interest arises with its insured.

A final problem with the ABA proposal is that it puts a great deal of pressure on insurance company counsel to correctly judge when a potential conflict of interest arises. There are inany times when insurance company counsel beheves that it is in the best interest of the insured not to settle. In that regard, if the case is one in which the insured is not liable, why should a large settlement be made with the almost certain result that the insured's liability insurance premiums will be raised?

In suin, the "attorney-withdrawal" approach is not a sound solution to the problein that arises when a liability insurance company fails to settle within policy limits and the insured, subsequently, suffers a judgment in excess of those limits.

\section{Strict Liability Under Case LaW DEVELOPMENT-A SOLUTION?}

At first blush, strict products liability cases ${ }^{13}$ and Section $402 \mathrm{~A}$ of the Restatement (Second) of Torts ${ }^{14}$ would not seem to be sources of law for plaintiff-insureds who seek damages from their liability insurance companies because of their failure to settle within policy limits. These legal resources deal with sellers of chattels, and it would not be realistic to deem an insurance policy a chattel. ${ }^{15}$ In effect, although liability insurance is embodied in a document, it is a service that is being provided to policyholders. While some products liability cases have

13. See, e.g., C.C. Hooper Cafe Co. v. Henderson, 223 Ala. 579, 137 So. 419 (1931) (liability of manufacturer or seller for injury caused by food or food products sold); Wyatt v. Cadillac Motor Car Div., 145 Cal. App. 2d 423, 302 P.2d 665 (1956) (automobiles or other vehicles, and their parts, supplies, and equipment); Cordell v. Coca-Cola Bottling Works, 56 Ga. App. 117, 192 S.E. 228 (1937) (beverages); Henderson v. National Drug Co., 343 Pa. 601, 23 A.2d 743 (1942) (drugs or medicines); Coca Cola Bottling Works, Inc. v. Crow, 200 Tenn. 161, 291 S.W.2d 589 (1956) (containers or packages).

14. This section reads as follows:

(1) One who sells any product in a defective condition unreasonably dangerous to the user or consumer or to his property is subject to liability for physical harm thereby caused to the ultimate user or consumer, or to his property, if

(a) the seller is engaged in the business of selling such a product, and

(b) it is expected to and does reach the user or consulner without substantial change in the condition in which it is sold.

(2) The rule stated in subsection (1) applies although

(a) the seller has exercised all possible care in the preparation and sale of his product, and

(b) the user or consumer has not bought the product from or entered into any contractual relation with the seller. RESTATEMENT (SECOND) OF TORTS $\S 402 \mathrm{~A}(1965)$.

15. See R. Brown, The Law of Personal Property $\$ \$ 5,6,59$ (2d ed. 1955). 
extended their reach to services, a tangible chattel has played an essential part in the transaction and has been a substantial cause of the physical harm suffered by the plaintiff. ${ }^{10}$

Nevertheless, if one reaches below the surface to the reasons that underlie Section 402A of the Restatement (Second) of Torts and cases that have imposed strict liability on sellers of products, one finds a more fertile resource for the imposition of that very same liability on liability insurance companies when their failure to settle has cost a policyholder inoney.

First, strict liability has been imposed on manufacturers of products because negligence law was found to be an insufficient imcentive to compel manufacturers to make products safe. ${ }^{17}$ The sanre situation apparently exists with regard to liability insurance coinpanies. While there are numerous cases each year where plaintiff-insureds prevail against liability insurance companies and prove that they have exercised "bad faith" or that they were negligent in failing to settle, ${ }^{18}$ there are also many where plaintiff is unable to do so. ${ }^{19}$ Under the "bad

16. See, e.g., Chevron Oil Co. v. Sutton, 85 N.M. 679, 515 P.2d 1283 (1973) (repair of automobile wheel); Newmark v. Gimbel's, Inc., 54 N.J. 585, 258 A.2d 697 (1969) (application of permanent wave solution); Carpenter v. Best's Apparel, Inc., 4 Wash. App. 439, 481 P.2d 924 (1971) (application of permanent wave solution). But see Buckeye Union Fire Ins. Co. v. Detroit Edison Co., 38 Mich. App. 325, 196 N.W.2d 316 (Ct. App. 1972) (sale of electrical service).

17. See Henningsen v. Bloomfield Motors, 32 N.J. 358, 391, 161 A.2d 69, 87 (1960); W. Prosser, The Law of TorTs $\$ 97$, at 650 (4th ed. 1971). Contra, Plant, Strict Liability of Manufacturers for Injuries Caused by Defects in Products-An Opposing View, 24 TENN. L. REv. 938, 945 (1957).

18. See, e.g., cases cited in notes 3 \& 4 supra; Keeton, supra note 1 , at 1139-40 nn. 6-8. See also Snow, supra note 1 , at 52 .

19. Hodges v. Standard Accident Ins. Co., $198 \mathrm{Cal}$. App. 2d 564, 18 Cal. Rptr. 17 (1961) (refusal to settle $\$ 50,000$ suit within $\$ 10,000$ policy limits did not render insurance company liable for $\$ 27,000$ judgment); Kohlstedt v. Farm Bureau Mnt. Ins. Co., 258 Iowa 337,139 N.W.2d 184 (1965) (refusal to settle $\$ 100,000$ suit within $\$ 15,000$ policy limits was not bad faith establishing liability for $\$ 25,000$ verdict); Ferris v. Enployers Mut. Cas, Co., 255 Iowa 511, 122 N.W.2d 263 (1963) (failure to settle within $\$ 10,000$ policy, resulting in $\$ 55,000$ judginent against insured, did not make insurance company liable for difference); Peterson v. American Family Mnt. Ins. Co., 280 Minn. 482,160 N.W.2d 541 (1968) ( $\$ 125,000$ suit, $\$ 35,500$ recovery; policy $\$ 10,000$; failure to settle did not lead to liability for excess over policy amount); Gordon v. Nationwide Mut. Ins. Co., 30 N.Y.2d 427, 285 N.E.2d 849, 334 N.Y.S.2d 601 (1972), cert. denied, 410 U.S. 931 (1973) (failure to settle within $\$ 20,000$ policy because of erroneous belief that policy was cancelled would not involve bad faith rendering company liable for $\$ 259,000$ judgment); Cowden v. Aetna Cas. \& Sur. Co., 389 Pa. 459, 134 A.2d 223 (1957) (no liability for $\$ 45,000$ excess judgment when company refused to contribute policy limit toward settlement in which insured was prepared to join); Alford v. National Emblem Ins. Co., 225 Tenn. 379, 469 S.W.2d 375 (1971) (failure of insurance company attorney to interview investigating officer about insured's accident or to make 
faith" and negligence standards, insurance companies apparently believe that it is a worthwhile risk to gamble. Moreover, to a great extent, they may gamble with the insured's inoney. For example, suppose the insured has an automobile liability insurance policy with a $\$ 20,000$ inaximum coverage per accident. The possible liability exposure of the insured is $\$ 100,000$, but there is a potentially good assumption of risk defense. If an offer is made to settle at $\$ 20,000$, the insurance company can refuse it and gamble with $\$ 80,000$ of the insured's assets. ${ }^{20}$

Second, and inore importantly, strict liability has been imposed upon manufacturers of products because they impliedly represent or warrant that the product is reasonably fit for its intended use. ${ }^{21}$ The purchaser of liability insurance with a $\$ 20,000$ limitation stands in a situation quite analogous to the purchaser of a product: he expects to be safeguarded against any tort claim that is inade for less than that anrount. ${ }^{22}$ When there has been a refusal to settle within policy limits

effort to settle within policy limits not bad faith); Aetna Cas. \& Sur. Co. v. Price, 206 Va. 749, 146 S.E.2d 220 (1966) (insurance company which carefully investigated and then refused to settle malpractice case within policy limits not liable for $\$ 50,000$ excess judgment).

20. The incentive to take such risks naturally increases as settleinent offers approach policy limits, even though the insured has nothing to gain and may well lose by litigation. Insurance companies should, therefore, be willing to assume the burden as well as the benefits of a decision to litigate rather than settle. See Sinith, supra note 1, at 700; Comment, Applying the Bad Faith Doctrine, supra note 6, at 284-85; Coinment, Insurance, supra note 6, at 101-02; Comment, Insurer's Liability, supra note 4, at 154; Note, Excess Liability: Reconsideration of California's Bad Faith Negligence Rule, 18 Stan. L. Rev. 475, 482-85 (1966); 13 U. CHI. L. Rev. 105 (1945); Note, Insurer's Refusal to Settle-A Proposal for Imposition of Liability Above Policy Limits, 60 YALE L.J. 1037 (1951).

The insured has nothing to gain from a trial if he could be protected from personal liability by a settlement, with two qualifications. First, he may gain if he is found not liable, since his premiums will probably rise in the event he is adjudged liable or the case is settled, though the increase in premiums would generally be less than the possible judgment against him. Second, the insured may want a trial in order to vindicate himself-he inay want the chance to prove his case.

21. See, e.g., Henningsen v. Bloomfield Motors, 32 N.J. 358, 384-85, 161 A.2d 69, 83-84 (1960); W. PRosSER, supra note 17, §97, at 651 (4th ed. 1971).

On whatever theory, the justification for the strict hability has been said to be that the seller, by marketing his product for use and consumption, has undertaken and assumed a special responsibility toward any nember of the consuming public who may be injured by it; that the public has the right to and does expect, in the case of products whicls it needs and for which it is forced to rely upon the seller, that reputable sellers will stand behind their goods ..... RESTATEMENT (SECOND) OF TORTS $\$ 402 A$, comment c (1965).

22. Under this view, an ultimate result of strict liability would be to afford a type of coverage which the insured would probably prefer, and one which le may even feel he is buying already, "but which he is far too weak to obtain by bargaining." Cominent, 
and a subsequent judgment in excess of that limitation, the buyer's common sense expectation has been thwarted.

Courts have recognized the fact that insureds believe "that a sum of money equal to the limits [of the policy] is available and will be used so as to avoid hability on [the insured's] part with regard to any covered accident." ${ }^{23}$ Thus, a number of jurisdictions have implemented this expectation through the use of "presumptions" that deein the insurer's failure to foresee an excess recovery as prima facie evidence of its negligence in refusing to settle. ${ }^{24}$ Actually, these courts are only giving lip service to the fault system. In the glare of hindsight, the fact that a claimant has won an excess judgment should not in and of itself be evidence that the insurer was negligent in refusing to settle. Nevertheless, these courts are pressed into that position because they want to fulfill what they believe to be the reasonable expectations of the consumer. ${ }^{25}$

Finally, strict hability is imposed on inanufacturers of products because they are in a good position (especially as compared with pur-

Crisci's Dicta of Strict Liability for Insurers' Failure to Settle: A Move Toward Rational Settlement Behavior, 43 WASH. L. Rev. 799, 816 (1963).

23. Crisci v. Security Ins. Co., 66 Cal. 2d 425, 431, 426 P.2d 173, 177, 58 Cal. Rptr. 13, 17 (1967); accord, Rova Farms Resort, Inc. v. Investors Ins. Co. of America, 65 N.J. 474, 501-02, 323 A.2d 495, 510 (1974). See also Fletcher v. Western Nat. Life Ins. Co., 10 Cal. App. 3d 376, 403-04, 89 Cal. Rptr. 78, 95 (1970); Reichert v. General Ins. Co., 68 Cal. 2d 822, 849, 442 P.2d 377, 393, 69 Cal. Rptr. 321, 337 (1968) (dissent; 4-3 decision).

The quasi-public nature of the insurance industry, along with the adhesive character of much of the dealing between insured and insurer, has led courts to give special weight to the reasonable expectations of the public and to the type of service the insurance company holds itself out as offering. Barrera v. State Farm Mut. Auto. Ins. Co., 71 Cal. 2d 659, 668 n.5, 456 P.2d 674, 680-81 n.5, 79 Cal. Rptr. 106, 112-13 n.5 (1969); Note, Good Faith and Fair Dealing in Insurance Contracts: Gruenberg v. Aetna Insurance Co., 25 Hastings L.J. 699, 707-08 (1974).

24. See, e.g., Radio Taxi Serv., Inc. v. Lincoln Mut. Ins. Co., 31 N.J. 299, 305-06, 157 A.2d 319, 323 (1960). The argument is that the fact of the excess judgment in itself invites the inference that the refusal to settle was unreasonable. Comment, $A p$ proaching Strict Liability, supra note 4, at 720. Strictly speaking, of course, it supports only the inference that the judginent was wrong, not the inference that it was unreasonable or negligent.

25. Strict liability would be a more straightforward method of fulfilling the insured's expectations. Further, courts could then inake it absolutely clear that the duty was imposed by law and could not be avoided by contract except under certain circumstances; note that the proposed statute does allow an insurer to avoid this liability on contracts sold at a reduced premium. General Regulation Article, $\$ 4$. This would parallel products liability, where a seller is not allowed to disclaim, dilute, or alter by contract the duty which the law imposes on him. See, e.g., Greeno v. Clark Equip. Co., 237 F. Supp. 427, 431 (N.D. Ind. 1965); Dart Equip. Corp. v. Mack Trucks, Inc., 9 CaI. App. 3d 837, 849, 88 Cal. Rptr. 670, 678 (1970). 
chasers) to distribute the costs of the accident. ${ }^{26}$ Liability insurance companies are also in that position. They can make a reasonably accurate estimate of the cost of "excess judgments" and distribute that cost through the price of liability insurance policies. ${ }^{27}$

Although it can be seen that all the important policies underlying strict liability in regard to manufacturers of products are at least equally applicable to liability insurance companies, it may be objected that the application of strict liability to any pure service is a dangerous precedent which could lead to a subjection of all services to the same standard. ${ }^{28}$

This is an unreasonable concern. The reliance that the consumerinsureds place on being protected from liability up to the limits of their policies is almost umique. With respect to most other services, the consumer only anticipates "reasonable care." More importantly, sellers of insurance policies are in a much better position to distribute costs of potentially increased liability on a widespread basis than sellers of other services; they are a service that deals with hundreds of thousands and sometimes millions of customers. ${ }^{29}$ Finally, the insurance company's

26. See 2 F. HARPER \& F. JAMES, THE LAW OF TORTS $\$ 28.19$, at 1576 (1956); W. Prosser, supra note 17, \& 75, at 494 (4th ed. 1971).

[P]ublic policy demands that the burden of accidental miuries caused by products intended for consumption be placed upon those who market them, and be treated as a cost of production against which liability insurance can be obtained; and that the consumer of such products is entitled to the maximum of protection at the hands of someone, and the proper persons to afford it are those who market the products. RESTATEMENT (SECOND) OF TORTS $\$ 402 \mathrm{~A}$, comment c (1965).

But see Plant, supra note 17, at 945-48.

27. See Comment, supra note 22 , at 806.

28. Even courts most favorably disposed to strict liability have shied away from the conccpt when professional services are involved. See, e.g., Carmichael v. Reitz, $17 \mathrm{Cal}$. App. 3d 958, 95 Cal. Rptr. 381 (1971); Magrine v. Spector, 53 N.J. 259, 250 A.2d 129 (1969); 41 TenN. L. Rev. 392, 396-99 (1974). See generally Farnsworth, Implied Warranties of Quality in Non-Sales Cases, 57 Colum. L. Rev. 653 (1957); Note, Products and the Professional: Strict Liability in the Sale-Service Hybrid Transaction, 24 Hastings L.J. 111 (1972); Note, The Application of Implied Warranties to Predominantly "Service" Transactions, 31 OHro Sr. L.J. 580 (1970). But cf. Johnson v. Sears, Roebuck \& Co., 355 F. Supp. 1065 (E.D. Wis. 1973) (on defendant's motion to dismiss, held public policy does not require as a matter of law that mechanical and administrative services provided by hospitals be exempt from strict hability); St. Johnsbury \& Lamoille County R.R. v. Canadian Pac. Ry., 341 F. Supp. 1368 (D. Vt. 1972), aff'd, 469 F.2d 1395 (2d Cir. 1972) (dictum expressed readiness to extend strict liability to a pure service contract if given an "appropriate" case); Hoffmann v. Misericordia Hosp., $439 \mathrm{~Pa}$. 501, 267 A.2d 867 (1970) (on defendant hospital's demurrer, held that even if giving blood seen as a service, hospital might be liable for breach of warranty).

29. Even if higher premiums were to result, they would be borne by the class directly benefited-the pohicyholders-and would also be consistent with public policy favoring greater distribution of risks. See Note, An Insurance Company's Duty to Set- 
misjudgments in these matters can be distinguished from those made by most other services: the company had a full and ample time period to provide its insured full protection and consciously decided not to provide it. ${ }^{30}$

The benefits that will be derived from the imposition of strict liability are clear. Thus, in the event of an accidental loss accompanied by a settlement within policy limits, insureds will be protected against serious and substantial economic injury as well as from the inental suffering that occurs when the insurance company has "guessed wrong."31

The imposition of strict liability will provide an additional benefit: it will remove one of the most significant thorns of potential "conflict of interest" from the side of the legal profession. ${ }^{32}$ In that connection, insurance company counsel will no longer be torn between his obligation to his employer and his "client for the case" when there is a decision to decline an offer of settlement. He can simply exercise his best judgment from the vantage point of the insurance company. His other "chent" will be protected in case that judgment is wrong.

Finally, while the overriding imposition of strict liability may increase costs of insurance simply because the companies may have to "pay out more," it may also result in some savings. First, the insurance compamies will be operating under clear and predictable rules. This will reduce or ehininate costly litigation over "excess liability coverage." Also, the insurance company will avoid being subject to liability for infliction of emotional harm or for punitive danrages because of its failure to settle. Since the insured will know that he will be protected from excess hability and the duty on the insurance company will be clear, danrages of either kind will be unlikely to arise. As some recent

tle: Qualified or Absolute?, 41 S. CAL. L. Rev. 120, 139 (1968); 13 U. CHI. L. Rev. 105,110 (1945).

30. In effect, the insurer has taken a risk by its own choice. Under products liability, a beer bottler is liable for exploding bottles no matter how careful lee was; a fortiori he would be liable if he knew that a specific bottle might explode but nevertheless chose to sell it and hope for the best.

31. See, e.g., Crisci v. Security Ins. Co., 66 Cal. 2d 425, 426 P.2d 173, 58 Cal. Rptr. 13 (1967); cf. Eckenrode v. Life of America Ins. Co., 470 F.2d 1 (7th Cir. 1972) ("outrageous conduct" by life insurance company in denying liability to beneficiary); Gruenberg v. Aetna Ins. Co., 9 Cal. 3d 566, 510 P.2d 1032, 108 Cal. Rptr. 480 (1973) (breach of good faith by fire insurance company to policyholder supports damages for mental distress); Fletcher v. Western Nat'l Life Ins. Co., 10 Cal. App. 3d 376, 89 CaI. Rptr. 78 (1970) ("outrageous conduct" by disability insurer supports damages for emotional distress).

32. See, e.g., R. KeEton, supra note 3, § 7.7a (1971); Annot., 28 A.L.R.3d 389, 396 (1969). 
verdicts indicate, damages for "emotional harm"33 or punitive damages $^{34}$ can be quite substantial.

Although common law strict hability represents an improvement over either a negligence or good faith basis for imposing hability when an insurer has failed to settle within pohcy limits and an excess judgment has been rendered against its insured, it is not the best way to resolve the matter. ${ }^{35}$ There is a danger of judicial overkill in the application of strict hability for insurance companies' failure to settle: courts may require the company to initiate settlement discussions or hold it responsible for damages that an insured would clearly be unable to pay. ${ }^{36}$ More importantly, a strict liability system developed by case law will fail to provide the predictability that is of vital concern to both the insurer and the insured. ${ }^{37} \mathrm{~A}$ system that is fair to all parties therefore must be based on legislation. That legislation must attempt to balance the needs of the insurer and the insured, be practical in design, and resolve the nuajor dilemmas that have confronted courts for too many years.

\section{Statutory Strict Liability: A Solution.}

A proposed statute is offered in the Appendix to this Article in order to provide state legislatures with a starting point for resolving

33. See cases cited in note 31 supra. See also Parks, IV, Heil, Insurers Beware: "Bad Faith" Is in Full Bloom, 9 ForUM 63 (1973); Comment, 47 NEB. L. REv., supra note 4, at 720; Note, Damages for Mental Suffering Caused by Insurers: Recent Developments in the Law of Tort and Contract, 48 Notre DAME L. Rev. 1303 (1973).

It has even been suggested that an insured in an excess judgment situation should be allowed to assign his claims to plaintiff, relieve himself of further liability, and still sue separately for mental and emotional damages. Comment, Wrongful Failure to Settle an Insurance Claim: The Case of the Missing Cause of Action, 20 U.C.L.A.L. Rev. 1408 (1973).

34. State Farm Mut. Auto Ins. Co. v. Smoot, 381 F.2d 331 (5th Cir. 1967), cert. denied, 390 U.S. 1005 (1968).

35. To date only two courts, in dictum, have indicated that they might shift to a strict liability basis. Crisci v. Security Ins. Co., 66 Cal. 2d 425, 430-31, 426 P.2d 173, 177, 58 Cal. Rptr. 13, 17 (1967); Rova Farms Resort, Inc. v. Investors Ins. Co., 65 N.J. 474, 500-02, 323 A.2d 495, 509-10 (1974). Seven years after the Crisci dictum was handed down, Rova Farms characterized strict liability as having been "regarded favorably by some," but the court went no further than to admit "the probability or the possibility" of future judicial adoption of the rule.

36. Cf. Ammerman v. Farmers Ins. Exch., 22 Utah 2d 187, 450 P.2d 460 (1969).

37. Appraising the California experience with bad faith, one writer said that "almost every other action filed on a property insurance claim now includes a prayer for damages in excess of policy limits." Bogert, Liability of Insurers in California Beyond Policy Limits, 1973 INS. L.J. 381, 382 (1973). Precise regulation of recovery in such actions would have a substantial impact on the industry. Also, since today's judicial standards often amount to the functional equivalent of strict liability, the number of suc- 
when a liability insurance company should be liable to its insured for its failure to settle a claim. For the reasons set forth in Part II of this Article, strict liability has been selected as the basis for insurance coinpanies' liability. Nevertheless, every reasonable attempt is made to limit that liability to situations where it is absolutely necessary to impose it.

The statute makes it clear that liability insurance must protect an insured when the imsurance company declines an "offer of settlement" and there is a subsequent judgment against the imsured above the limits of the liability insurance policy. This obligation is embodied in the first section of the General Regulations Article of the proposed statute.

The statute defines what an "offer of settlement" is for this purpose in section 2 of the General Regulations Article. Several questions are resolved. For example, the offer need not be tendered in writing -it may be conveyed orally by plaintiff's attorney. This approach was taken because most offers of settlement are made on the telephone or in face to face meetings; thus, too inany offers would be eliminated if they were required to be in written form. The principal argument for requiring that the offer be made in writing would be to avoid fraudulent claims. The possibility of fraud by an injured plaintiff's counsel seems remote. Moreover, counsel would liave little to gain by making such a fraudulent claim because under the proposed system the insurer would be liable for an excess judgment only when the insured would, in fact, be able to pay the claim..$^{38}$ The more serious threat is that of fraud by an insured who falsely alleges that the insurer refused an oral offer to settle; nevertheless, an insured is unlikely to be able to manufacture substantial proof of that kind. In sum, the possibilities of fraud are not so great as to justify a loophole allowing insurers to refuse any oral offer with impunity.

The primary purpose of the statute is to protect the insured from the insurer's decision not to settle. Thus, if the insured concurs in that decision for his own reasons, then the arguments for protecting him evaporate. The statute requires that in order for an insured to waive his rights once there has been an offer to settle, lie must reject the settlement affirmatively and in writing. This requirement will reduce the problems of proving rejection, and provide some protection against pressure exerted by the insurer.

cessful recoveries against insurance companies should not increase drastically. See Snow, supra note 1, at 54; Note, Excess Liability, supra note 20, at 484; 23 U. FLA. L. REv. 201 (1970).

38. See text accompanying note 39 infra. 
Should there be an obligation on the insurance company to initiate settlement? There is a temptation to require the insurer to make an attempt to settle a dispute, because this duty might facilitate early resolution of claims and provide additional protection for an insured. The benefits, however, would come at too high a price. Two of the principal dividends of a statutory system for the handling of excess liability claims are a predictable standard that will keep disputes about failure to settle out of the courts and the avoidance of conflict-of-interest problems for insurance company attorneys. If an obligation were placed on the insurance company to initiate settlement, both benefits would be compromised. For example, the duty to imitiate settlement would have to be phrased in terms of a "reasonable effort." One can readily foresee that there would be litigation as to whether a "reasonable effort" was made and that the insurance company attorney would again be placed in a conflict-of-interest position. In sum, many of the vexing problems that have plagued the courts with the good faith and neghigence standards would return in a new form if an insurance company had a duty to mitiate settleinent.

The statute specifies the amount of money the liability insurance company becomes responsible to pay when an excess judgment has been rendered against its insured. Two basic alternatives are the amount of the final judgment or the amount the insured could actually pay. This author would limit the responsibility of the insurance coinpany to the amount that a successful plaintiff "would liave been able to recover from the insured," 39 and the statute so provides in section 3 of the General Regulations Article. ${ }^{40}$ In order to implenient that rule, the state Insurance Commissioner would be authorized to establish an administrative procedure which would determine whether the

39. Cf. Shapiro v. Allstate Ins. Co., 14 Cal. App. 3d 433, 92 Cal. Rptr. 244 (1971). See generally R. KEETON, supra note 3, $\$ 7.8(\mathrm{f})$, at 516-20, agreeing with this conclusion. Professor Keeton gives as one of his reasons for this conclusion the fact that the plaintiff offered to settle for the lesser amount, and therefore has in a sense benefited from the refusal to settle since he now has a judgment for more than what he offered to accept. $I d$. at 517 . This is true, but subject to a significant qualification: the judgment today may be worth less than the settlement was when it was offered for two reasons. First, the judgment is not money, but only a right to get money, and therefore may be of less value than the offered settlement would have been if paid. Second, the plaintiff, in order to get the judgment, has had to wait, losing the use of money, and has incurred expenses-the attorney's contingent fee alone may reduce an apparently generous judgment to a sum less than the offered settlement. See generally Annot., 63 A.I.R.3d 627 (1975).

40. While it is true that section 5 makes the judginent collectible as soon as it becomes final, the amount collectible is limited by section 3 to the amount that could be collected from the insured. 
insured could now, or in the immediate future, pay the excess. The commissioner's authority to proceed is also set forth in section 3.

It might be argued that this rule is unfair to the injured plaintiff since he may be denied the benefit of his full jury award; however, this argument does not withstand close analysis. The insurance company's responsibility to pay a judgment in excess of the policy limits arises out of a duty to indemnify its insured for its failure to accept an offer to settle and not out of any duty to the plaintiff who suffered an injury. In any case, the plaintiff is denied nothing by this rule, since the amount recoverable is defined in section $3 \mathrm{~A}$ of the General Regulations Article as the insurance policy limits plus so much of the insured's assets as would be subject to judicial process; that is the most the plaintiff could recover fron the insured without the statute.

The statutory systeni could also resolve another problem that has troubled courts recently: it can specify the extent of the insurer's obligation toward its insured when there has been an offer to settle in excess of the limits of the policy. ${ }^{41}$ In that situation, the insurer should notify the insured of the existence and amount of the offer. If the insured indicates in writing that he is willing and able to supply the funds in excess of the policy limit that are necessary to settle the claim, he should then have the benefit of placing the risks of a refusal to settle on the insurance company. For example, if the policy limit is $\$ 10,000$ and there is an offer to settle for $\$ 12,000$, then the insurance company should inform the insured of the offer and give him an opportunity to contribute $\$ 2,000$. If he does make the contribution, then the insurance conipany can settle for $\$ 10,000$, the policy limit; if it refuses to do so, it should be required to pay any judgment in excess of the policy limit. Once the insured offers to contribute enough for the insurer to settle at the policy limit, the situation is indistinguishable from one in which the plaintiff offers to settle at the policy limit. If the insurer prefers to gamble, it should do so at its own risk. This approach follows from the basic strict liability system set forth in the statute, and will provide both the insurer and the insured a clear understanding of their respective responsibilities in the situation. The suggested approach to this problen is set forth in section 2 of the General Regulations Article of the proposed statute.

Another issue for statutory resolution is that of who may enforce the insurer's liability for the excess judgment. ${ }^{42}$ Although the liability

41. Cf. Brochstein v. Nationwide Mut. Ins. Co., 448 F.2d 987, 989-90 (2d Cir. 1971), cert. denied, 405 U.S. 921 (1972) (failure to inform the insured that a settlement might be possible if he will contribute toward it may show bad faith).

42. See Annot., 63 A.L.R.3d 677 (1975). 
arises out of a duty to the insured, and not to the injured plaintiff, the best rule would be to allow either the insured or the plaintiff to enforce it. The advantage of allowing the plaintiff to enforce it is efficiency: there is no point in requiring a suit against the insured for failure to pay a judginent. The advantage of permitting the insured to enforce it is protection: the insured must have some recourse if the plaintiff chooses to enforce his judgment against the insured's assets. The proposed statute deals with this issue in section 5 of the General Regulations Article.

There are many other matters that could be resolved in a statutory strict liability scheme. A carefully conducted, thorough legislative hearing on the matter has a greater potential than case law for bringing the important issues to hight and resolving thein in a proper manner. The legislative system certainly could avoid many of the untoward consequences that might arise froin common law application of strict hability. Thus, if the "offer of settleinent" procedure is carefully spelled out in the legislation, insureds would not be tempted to obtain insurance with low liability limits in the hope that they will be protected by strict hability for excess judgments. The insurance seller can demonstrate to the buyer that if his protection has too low a limit, there will be little likelihood of an offer of settlement within the policy limits in case of a serious accident.

Finally, the legislature can utilize options that may be impossible or extremely difficult to develop by common law decision. For example, a statute could set forth when and under what conditions a hability insurance company might be entitled to contract out of its responsibility for excess judgments based on failure to settle. ${ }^{43}$ An approach to this problein is set forth in section 4 of the General Regulations Article of the proposed statute.

\section{CONCLUSION}

Current legal approaches to the problen of harm caused by an insurance company's failure to settle have left those companies, their attorneys, and policyholders uncomfortable and uncertain. The apphication of strict liability to such situations can be supported by reason and policy. Nevertheless, if strict liability is painted with too broad

43. A broad analogy may be provided by workmen's compensation statutes that provide procedures by which an employee can elect to pursue a common law, third party suit. See, ARIz. Rev. Stat. ANn. \& 23-1023 (Supp. 1974); Colo. Rev. Stat. AnN. § 81-13-8 (Supp. 1971); Del. Code ANN. tit. $19 \$ 2363$ (Supp. 1970); Mass. ANN. LAws ch. 152; \& 15 (Supp. 1974). 
a brush, as it might be if left to common law development, it may impose unreasonable costs on the insurance companies and on the price of insurance itself. Also, case law development of the strict liability doctrine will not provide the certainty that is of parainount importance in this area. On the other hand, a system of statutory strict liability can provide that predictability and protect the insured while avoiding overkill against liability insurance companies. This is a solvable problem that has plagued insurance compamies, their attorneys, and policyholders for too long. It is time for state legislatures to act. 


\section{APPENDIX}

\section{Proposed Statute}

\section{STATE INSURANCE CODE}

\section{GENERAL SECTION-LIABILITY INSURANCE}

Sub-SeCtion-General Regulations

\section{ARTtCle No. 001. FarluRe to Settle by an Insurer:} General Regulations

1. Strict Liability for Failure to Settle. When an insurer rejects an offer of settlement of a tort claim brought against its insured that is within the subject nnatter coverage and liability limits of its insurance contract, and a subsequent final judgment is entered against the insured in favor of the offering party that is in excess of the amount of such liability limits, the insurer inust pay such offering party the amount that such offering party would have been able to recover from the insured. Sucli ainount shall be determined pursuant to the procedure set forth in section 3 below.

2. Offer of Settlement. In order to constitute an offer of settlement for purposes of section 1 above, the offer must be tendered orally or in writing by the claimant or his attorney or authorized representative to the insurer or its attorney or authorized representative. Any such offer of settlement must be communicated by the imsurer to its insured within one week from the date it is received by the insurer. If the insured rejects the offer in writing, the insurer shall have no liability as set forth in section 1 above. If the amount of the offer of settlement is equal to or less than the liability limits of the insurance contract, and the insurer rejects the offer of settlement, then the imsurer shall be liable as set forth in section 1 above. If the amount of the offer of settlement is more than the liability limits of the insurance contract, the insured must be allowed to add his own funds to make up the difference between the offer and the liability limits of the insurance contract, im order to meet the offer; if the insured agrees to such addition in writing, and the insurer rejects the offer of settlement, the insurer shall be liable as set forth in section 1 above, but if the imsured does not so agree then the insurer shall not be liable under section 1.

\section{Determination of Excess Liability.}

A. When an insurer is liable for a judgment under section 1 above, the insurer shall pay the lesser of: 
(1) the entire judgment, or

(2) the sum of

a. the liability limits of the insurance contract, and

b. an amount equal to the value of so much of the insured's net assets as are subject to legal process under the laws of this state.

B. The Insurance Commissioner is empowered to determine the amount that is recoverable for purposes of subparagraph $A(2)$ (b) above, and for that purpose is empowered to conduct hearings pursuant to the applicable admimistrative procedure in this state, and to appoint up to ( ) assistants with authority to conduct such hearings.

C. Payment by the insurer of the amount described in subsection A, or of any lesser amount that relieves the insurer of further liability (whether under a compromise agreement with the offering party, now a judgment creditor, or otherwise), shall be deemed a full satisfaction of the judgment by the insured for purposes of relieving the insured of hability on the judgment.

4. Exemption from Strict Liability. An insurer, after clearly and fully explaining in writing to a prospective insured the obligation imposed upon the insurer by section 1 above, may offer to the prospective insured an insurance contract exempting the insurer from the provisions of this Article; provided, that any such contract shall be offered at a discount from the otherwise applicable premium (or other consideration paid to the insurer or by the insured). The reduction in premium shall reflect the reduced exposure of the insurer, and the Insurance Commissioner is authorized to establish the amount or proportion of the reduction. If the insured purchases such a discounted contract, the insurer shall be hable under section 1 of this Article only if the insurer

a. fails to act in good faith with respect to the insured, or

b. fails to make a reasonable attempt to notify the insured of an offer of settlement within one week of receiving it.

5. Payment Due. The liability, if any, of an insurer under this Article arises when the judgment against the insured becomes final and the amount of liability has been determined under section $3 \mathrm{~A}$, and shall be enforced by any court of appropriate jurisdiction upon petition of the insured or of the offering party now a judgment creditor. 
Sub-Section-Required Policy Provisions

Article No.001. Failure to Settle by an Insurer:

Required Policy Provisions

A policy insuring against loss or damage resulting from liability in tort for injury suffered by another person or damage to property shall not be issued or delivered in this state or to a resident of this state unless it contains either

(a) A provision that whenever an offer of settlement of a claim against the insured within the subject matter coverage and liability limits of the policy is tendered in accordance with Article No. 001 of the General Regulations of the Insurance Code of this State and is rejected by the insurer, and a subsequent final judgment is entered agamst the insured in favor of the offering party in excess of the amount of such liability limits, the insurer will pay such offering party the amount that such offering party would have been able to recover from the insured, such amount to be determined in accordance with Article No. 001 of the General Regulations of the Insurance Code of this State; or

(b) A provision, set in conspicuous type at least as large as follows that IN CONSIDERATION OF THE SPECIAL DISCOUNTED PREMIUM PAID FOR THIS POLICY, THE INSURER IS EXEMPT FROM THE OBLIGATION THAT WOULD OTHERWISE BE IMPOSED ON IT BY LAW TO PROTECT THE INSURED FROM AN OBLIGATION TO PAY A CLAIMANT AN AMOUNT IN EXCESS OF THE AMOUNT OF THE POLICY LIMTTS WHEN THE INSURER HAS REJECTED AN OFFER OF SETTLEMENT FROM THE CLAIMANT WITHIN THE LIMITS OF THE POLICY; INSTEAD THE INSURED WILL BE OBLIGATED TO PAY THE EXCESS AMOUNT UNLESS THE INSURER HAS FAILED TO EXERCISE GOOD FAITH OR HAS FAILED TO MAKE A REASONABLE ATTEMPT TO NOTIFY THE INSURED OF AN OFFER OF SETTLEMENT. 
